\title{
政 \\ Református szegénygondozás a 16. században
}

\section{Ferenczi Gábor}

\author{
Debreceni Egyetem Egészségügyi Kar \\ Alkalmazott Társadalomtudományi Tanszék
}

\begin{abstract}
Care about the poor of the Reformed Church in 16th century. The study deal with care about the poor of the Reformed Church in 16th century. Why is this age interesting particularly?As we know - among other events - this is the age of reformation and at the same time with theological changes started to change the way of looking at care about the poor and the needy.

A new, more anthropocentric conteption appeared ( certainly focusing on Scripture as the Word of God ) concentrating on solution of problems, instead of the previous church ideologies in the Middle Age. The study presents these new principles considering ideas of big reformers ( example Luther, Calvin ).

In addition to essay is about development of the system of diaconate and importance of described ideas for today social policy and social work.
\end{abstract}

Lektor: Prof. Dr. Fazekas Sándor, egyetemi tanár, rektor

Református Hittudományi Egyetem

DOI: $10.19055 / \mathrm{ams} .2011 .2 / 2 / 5$

\section{Bevezetés}

„A Jeremiás 22,16-ban ezt olvassukIzráel egyik királyának tevékenységéról: 'Jogához segítette a nyomorultat és a szegényt, ezért ment jól a dolga!Így tesz, aki ismer engem - igy szól az Úr.' Kálvin János a genfi reformátor azt mondja a fenti igeszakaszhoz fúzött magyarázatában: 'Ubi cognoscitur Deus, etiam colitur humanitas' 
(CO 38, 388), magyarul: 'Ahol ismerik Istent, ott az emberségre is gondot viselnek'. Ebben az egyetlen mondatban Kálvin teológiájának összefoglalását láthatjuk,..." 1

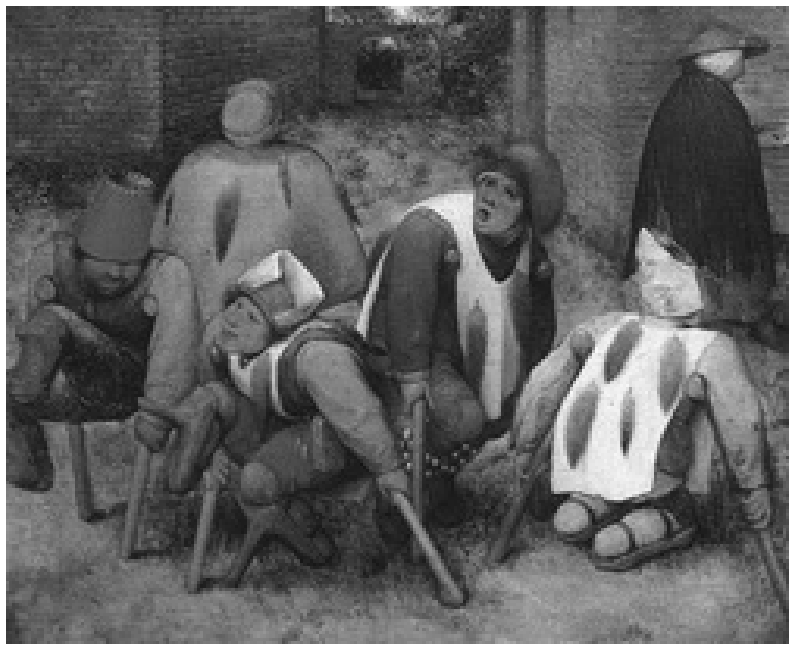

1. ábra. Pieter, Brueghel: Koldusok, 1568.

Milyen lehetett a református szegénygondozás (egyáltalán az elesettekrôl való gondoskodás) ebben a történelmileg nagyon meghatározó idôszakban, hogyan változott meg a korábbi szemlélethez képest a reformáció keresztyén vallást megújító ereje által a szegényekrôl való gondolkodás? Ez az izgalmas kérdés merült fel bennem és indított kutatásra, amikor témavezetôm felajánlotta számomra a címben szereplő terület vizsgálatát.

Szociális gondoskodás történetét tanítva azt már eddig is jól tudtam, hogy a reformáció hatására alapvetôen változott meg a középkori szegénygondozás, de érdekelt - és dolgozatomban errôl szeretnék egy a terjedelmi lehetóségeket is figyelembe véve vázlatos, de a fó jellemzőket mindenképpen kiemelni szándékozó képet adni -, hogy mi ennek az alapvetô változásnak az oka, a háttere, milyen új vallási teológiai gondolkodás az, amely ekkora változást tudott elérni, ekkora hatással tudott lenni a középkori szegénygondozás átalakulására?

Ennek a meghatározó szemléleti változásnak a gyökereit, gondolatainak összefüggố rendszerét természetesen a reformáció megújító erejében kereshetjük. Az új megközelítés lényegét és teljes körú magyarázatát a nagy reformátorok teológiai múveiben találhatjuk meg, így a valós korabeli szegénygondozói tevékenység rövid bemutatása mellett elsôsorban az ezen mûvekben megjelenố alapvetô "szociális

\footnotetext{
${ }^{1}$ Eberhard Busch: Istenismeret és emberség-Betekintés Kálvin János teológiájába ( Gotteserkenntnis und Menschlichkeit. Einsichten in die Theologie Johannes Calvins ) Magyarországi Református Egyház Kálvin János Kiadója, Budapest 2009. 7.
} 
gondolatokra" koncentráltam. Ezek közül is Kálvin erre a területre irányuló gondolati rendszerét emelem ki, hiszen az ô megközelítése látszik a legmeghatározóbbnak és a legmaradandóbbnak a fent leírt változás szempontjából.

Kálvin kezdetek óta új szövetség, együttmúködés kialakítására törekedett katedrális és városháza, egyház és közélet, hit és politika között. Véleménye szerint az egyháznak nem szabad visszahúzódnia a templom falai közé, hanem ki kell lépnie a történelem színpadára, s ott az emberi közösség összetartó erejét és fundamentumát kell alkotnia.

Az evangéliumi demokrácia első nagy hozadéka, egyént és közösséget önvédelmi fegyverrel ellátó szellemi terméke ez a polgári kritikai képesség volt, ez a „Made in Geneve", a genfi szellemiség. Vigyáztak arra, hogy ne legyenek túlzó, felesleges közkiadások, mérsékelték a pazarlókat, a hivalkodó újgazdagokat intették a luxus kerülésére mind a ruházkodásban, mind az étkezésben, mert ez a szegényeket még jobban megalázza. Az önmérséklet, a puritán jólét, a hivalkodást és kivagyiságot kerülő polgári tisztesség, kölcsönös tiszteletadás, a szegényt is emberszámba vevô szociális érzékenység - ez lett a genfi református gondolkodás és életstílus jellemzôje, a várost századok alatt magasba emelô genius locija. ${ }^{2}$

\section{A szegénység középkor végi társadalmi helyzete, új formái}

A középkorban a szegénység egyszerre jelenthetett elesettséget és emelkedettséget, ezzel együtt társadalmi bukást és lelki dicsőséget. A szegények összetétele nagyon színes volt, hiszen volt, akit környezete tett szegénnyé, mások szegénynek születtek, és akadtak, akik önként vállalták a szegénységet. Ez viszont nem tette lehetôvé sem egységes, sem koncepciózus szegénység-kezelés kialakítását. ${ }^{3}$

Szegénynek lenni a korszakban döntôen azt jelentette, hogy a szegénységgel érintett rászorul mások segítségére, viszont a szúkölködés nem jelentett mindenképpen társadalmi kitaszítottságot. Ugyanakkor jól látható az is, hogy a társadalom valamennyi rétegéből vezethettek utak ezen egyre szélesedő, a megélhetéssel küzdő, legalsó társadalmi csoportokba, melyekbe sokan vagy már eleve beleszülettek, vagy késóbb elszegényedtek. Az elszegényedés a középkorban nagyon változatos módokon következhetett be.

Meghatározó jelentőségúek (nem számítva a nagy társadalmi átrendeződéseket) a válságperiódusok, a népességrobbanások, a nagy járványok, a rendszeres háborúk és a természeti csapások. A középkor embere nagy mértékben kiszolgáltatott volt ezeknek a folyamatoknak és eseményeknek. Emellett a városokban a rossz termésú évek, az árdrágulás, a pénzhiány miatt is végigsöpörtek „,szegényhullámok”. Emiatt

\footnotetext{
${ }^{2}$ Dr. Békefy Lajos: Made in Geneva - Kálvin és Genf Reformátusok Lapja LII. évf. 43. sz. 2008. okt. 26.

${ }^{3}$ Mezey Barna: A munkaethosz és a szegényrendészet kriminalizálódása. In: Börtönügyi Szemle, 2009/3.,1.
} 
gyakori jelenség az iparosok, kereskedók és családjaik látványos elszegényedése és nyomora, akik különbözô gazdasági okokból mentek tönkre. Ugyanakkor a városba menekülő parasztok megfelelő ismeretek híján jellemzően alkalmi munkából élô, kiszolgáló vagy munkanélküli tagjává váltak a városi lakosságnak. Összességében tehát a szegénységet „,áplálták” a városi nyomorba zuhantak, a túzvészek, katasztrófák, árvizek áldozatai is.

A szegénység mértékének és az utazó nép számának megbecslésére kevés adat áll rendelkezésünkre, leginkább a történeti statisztika nyújt támpontot valamelyest, mely alapján Hans-Ulrich Wehler a szegények számarányát a 15. században 3050\%-ra, a 16. században 50-60\%-ra teszi. Ez a megdöbbentően magas adat lényegében azt jelenti, hogy a korszakban minden „nem szegényre” (nemesre, polgárra, parasztra, cselédre és zsellérre) jutott egy koldus, csavargó, beteg vagy rokkant. ${ }^{4}$

Az önkéntes szegénységet a hivatalos ideológia támogatása, az egyházi politika melletti lojalitás hívta életre. Tömegek keltek zarándokútra ${ }^{5}$, ajánlották fel vagyonukat az egyháznak, ill. választották az önként vállalt aszkézist, mellyel természetesen az országutak rászorultjainak számát növelték. Előkelő urak kolostorokat alapítottak, hölgyek vonultak vissza az élettől a zárdák falai mögé, hogy egyszerú, szegény, magányos életet éljenek. ${ }^{6}$ Az egyház megújítását célzó mozgalmak tulajdonképpen az apostoli szegénységhez való visszatérést hirdették, legtöbbször személyes példájukkal. Ezek egyik formája a városokban szervezett ún. testvérségek, melyeknek szintén az önkéntes szegénység volt az alapelve. ${ }^{7}$

\section{Korabeli erôfeszítések a szegénység kezelésére és ezek korlátai}

A középkorban természetesen az egyházi szegénygondozás magától értetôdô módon következett a keresztény karitász szelleméből, hiszen Máté evangéliumának értelmében $^{8}$ (jelen esetben a sok egyéb, ezt a gondolatot hangsúlyozó Szentírásbeli igére nem utalva) a keresztyén ember kötelessége az éhezóknek ételt adni, a szomjazókat megitatni, a ruhátlanokat felruházni, az idegeneket vendégül látni, a betegeket gondozni, a foglyokat meglátogatni. A keresztény szegénygondozás arra a tételre épült, mely szerint a kereszténység filozófiájában a könyörületesség alapvetô érték, keresztény erény, ami mintegy kötelezôvé teszi a nyomorult állapotban lévôk segítését. 9

\footnotetext{
${ }^{4}$ Wehler, Hans-Ulrich: Deutsche Gesellschaftsgeschichte I. München. Verlag C. H. Beck, 1987. 193.

${ }^{5}$ Wolf , Alois: Deutsche Kultur in Hochmittelalter (1150-1250). Essen, Akademische Verlagsgesellschaft Athenaion, 1986. 181-182.

${ }^{6}$ Boockmann, Hartmut: Die Stadt in späten Mittelalter. München, Beck, 1986. 254.

${ }^{7}$ Borst, Arno: Lebensformen in Mittelalter. Berlin, Propylän Verlag, 1973. 105.

${ }^{8} \mathrm{Mt} .25,35-36$.

${ }^{9}$ Castel, Robert: Les Métamorphoses de la question sociale, Paris, Fayard, 1995. (A mú egyes részletei megjelentek magyarul „A szociális kérdés alakváltozásai” címmel. In: „A tettetésnek minden mesterségeiben jártasok ...". Koldusok, csavargók, veszélyeztetett gyerekek a modernkori
} 
Ezzel együtt a korabeli keresztény felfogás is különbséget tett „,jó szegény” és „,rossz szegény” között, mely szerint rossz szegények voltak a világ isteni rendje ellen lázadók (hitehagyók, eretnekek). Viszont ennek ellene hatott az említett könyörületesség, a keresztény segítségnyújtással kapcsolatos felfogás, az az alaptézis, mely meghatározta a szegénygondozás módszerét, illetve késóbb a megváltható búnbánat gyakorlata. (Mint ismeretes, a vagyonosabb hívek az alamizsnatámogatás rendszerében megvásárolhatták lelki üdvüket, búnbánatukat.) Ez a rendszer - mely szerint tehát az egyházi segélyezést nem az intézményrendszer, hanem a segélyezés rendszere múködtette - egészen a reformáció kialakulásáig múködött. ${ }^{10}$

A szegénygondozásnak ez a "koncepciója" - ahol, mint a fentiekból láthatjuk, lényegében a segélyezési rendszer nem a segélyezettre, hanem a segélyezôre koncentrált - erôs befolyással volt a világi gondolkodásra is. Ezért nem jelenhetett meg a megelőzố gondoskodás eszméje, nem dolgozhattak ki átfogó tervet a szegénygondozás kezelésére sem, vagyis kvázi differenciálás és célmeghatározás nélkül osztottak pénzeket (ráadásul éppen ebben az idôszakban nagy mértékben elterjedt a koldulás).

Nem született valamilyen kidolgozott szempontrendszer mentén tevékenykedô és hivatásos szegénységkezelő szervezet sem, a segélyezésnek a meglévő struktúrákhoz kellett igazodnia. Ez a helyzet döntôen behatárolta a szegénygondozó tevékenység hatókörét és szinte egyedülállóan alkalmazottá tette az alamizsnaosztási technikát, mint segítségnyújtási formát.

Emellett egyszerûsítette a szegénygondozás koncepcióját az egyház meglevô szegénységképe és az ehhez igazodó gondozási praxis, amelyek azt is jelentették, hogy nem volt szükség kimunkálni valamiféle koncepciót, hiszen az készen állott. (Megjegyzendô, hogy term. az elóbbiekben vázolt komplex szegénység gyakran maga is nehezen engedett differenciált megközelítést.)

Megállapítható tehát, hogy középkor végére egyre nehezebben kezelhetôek a szociális problémák, a növekvő szegénység a hagyományos eszközökkel. Ennek meghatározó okai: a gazdasági múködés átalakulása, a kor erôsödő városiasodása ill. városi kultúra kiépülésének felgyorsulása és a kor vallási intoleranciája miatti migráció. Ekkorra már nem volt várható - korábban is csak esetleges segítséget jelentett - a középkori szegénységideáltól, a kolostori életformától, az alamizsnáskodástól, a koldus életforma isteni rendelésként való megjelenítésétôl az új (és az eddiginél nagyobb mértékû) szociális feszültségek megoldása. ${ }^{11}$

A fent bemutatott helyzetet értékelve jól látható, hogy szükséges lett volna leválasztani a középkori vallásos képrôl a valós hivatásos egyházi szegénységet, az önkéntes szegénységet, és egyértelmúen elhatárolni a munkakerülő, csavargó, kriminális elemekból álló koldus csoportokat a valódi rászorultaktól. Igaz, hogy a

Magyarországon. (Szerk. Léderer Pál, Tenczer Tamás, Ulicska László.) Budapest, Új Mandátum Kiadó, 1998. 30.5.

${ }^{10}$ Mezey i.m. 5.

${ }^{11}$ Dr. Fazakas Sándor: Kálvin szociáletikája in: Kálvin idôszerúsége-Tanulmányok Kálvin János teológiájának maradandó értékérôl és magyarországi hatásáról (szerk.: Dr. habil. Fazakas Sándor) Magyarországi Református Egyház Kálvin János Kiadó Bp., 2009. 124. 
városok tettek erre kísérleteket, a megoldás a reformáció koráig váratott magára.

A változásokra két - egymással is összefüggő - jelenség adott lehetőséget, hiszen egyrészt a szegénység struktúrája a 16-17. században alapvetően átalakult. Ennek magyarázata, hogy az iparosodás és a mezőgazdasági válság hatására, ill. az Európán átsöprő háborúk eredményeképpen óriási mértékben megnövekedett a városi szegények és a „hullámzó lakosság” száma. Ezen országutakon élô csavargó- és koldustömegek komoly rendészeti és igazságügyi feladatokat is jelentettek a hatóságok számára. Másrészt ezzel lényegében egy idôben mondhatni összeomlott a hagyományos gondozási rendszer. A társadalmi változások hatására átalakult szegénység „alkalmatlanná vált” a hagyományos kezelésre, akár az egyház alamizsnarendszerét vagy a városok zárt képletekhez igazodó saját szegény-gondozását vesszük figyelembe.

Az új eszközök keresésében kialakult és meghatározó lett a protestantizmus szegénység-elgondolása, ez a szegényektool is az eddigiektól eltérô magatartást várt el. A protestáns városigazgatás és államhatalom ehhez rendészeti eszközöket ( is ) csatolt, melynek hatására nagy változás indult meg a szegényügyben.

\section{A vezető reformátorok fellépése, szemléleti újításai}

\section{Luther és Kálvin}

A reformáció megjelenése, a Szentírás üzenetét középpontba helyezô hit megkérdőjelezte a szociális gondok megoldására tett korábbi módszereket. A kegyelemból hit által való megigazulás reformátori felfogása ugyanis megfosztotta a jótékonykodást érdemszerző jellegétôl. Luther felhívást intézett a német nemességhez a szegénység megszüntetésére, melynek hatására a városok figyelme a koldulás korábbi szabályozása helyett a szegények megsegítése felé fordult (pl. Kommunális szegénykasszák felállítása). Luther a keresztyén gyülekezettôl nagyobb aktivitást várt e tekintetben, s számára Isten a szegények istene és nem a gazdagoké, a szegénységnek nála inkább a lelki, mint a materiális oldala hangsúlyos (így nem lát összefüggést pl. a szegénység kezelése és a jobbágyság felszámolása között).

Kálvin a szegénység megítélésében a lutheri örökség vonalában áll, viszont ô már strukturális szinten szemléli és kívánja megoldani a kérdést ( ennek bemutatását ld. késôbb ). Kálvin Genfben átfogó és körültekintô módon látott neki a szegénygondozás rendszerének elméleti és gyakorlati kidolgozásához. ${ }^{12}$

A középkor végi gazdasági átalakulások miatt elszegényedő tömegek az iparosodottabb, gazdagabb városokba áramlottak, ahol megélhetést és munkát reméltek. Ezek a rétegek megjelenése viszont félelemmel töltötte el a lakosságot, és gyakran bünözóként kezelték a szegényeket, így a városok vezetése is a probléma sürgôs

\footnotetext{
${ }^{12}$ Fazakas S. i.m. 125.
} 
kezelését akarta elérni.

Természetesen találhatunk összefüggést a városok problémamegoldó törekvése és a reformátori tevékenység hatására felébredô felebaráti felelősségvállalás között, de egyben látnunk kell ezek szerencsés egybeesését is. Emellett Kálvin módszere ehhez megerősítést adott, aminek köszönhetően a keresztyénség szociális elkötelezettsége a reformáció döntô jellemzôjévé vált.

\section{A szegénység és a munka kapcsolatának új értelmezése}

A 16. század húszas éveiben Wittenberg környezetében jelentôs feszültség alakult ki a religio kérdése körül. A történettudomány ezt a korszakot a "wittenbergi nyugtalanság"-nak nevezi. Ekkor többek között 1521-ben a karlstadti pap a karácsonyi misét civil ruhában celebrálta, melynek hatására a felindult hívek a templom mellékoltárait tönkretették, a szenteket ábrázoló szobrokat és a Mária-alakot összetörték, feldarabolták és elégették. A következô év elején az ágostonrendiek konventje adott szabadságot testvéreinek annak eldöntésére, elhagyják-e a rendet, vagy maradnak ( ekkorra már szerzetesek sora hagyta el rendjét más szerzeteknél is ). A városvezetés reformációs tanácskozmánya pedig ugyanebben az idóben, tekintettel a polgárság viharos hangulatára a város egyetemén határozatokat fogalmazott meg a mise szabályozásáról, a szentképekról, a nyilvános erkölcstelenségek felszámolásáról és a koldulás megtiltásáról. Ezenkívül közperselyekbe helyezte a laikus testvérségek vagyonát és úgy rendelkezett, hogy ebból a forrásból kell finanszírozni a szegénygondozás újjászervezését. ${ }^{13}$

A protestáns gondolkodásmódnak ezek az egyházat, társadalmat formáló megnyilvánulásai szorosan összefüggtek a munka újszerü felfogásával, mely alapvetően átértékelte a szegénység szerepét a társadalomban. Az előzô időszakban a középkor szóhasználata a munkával kapcsolatban elismerte, hogy a munka szükséges az élethez, de nem általánosan szükséges kötelezettség. Ezt a szemléletet képviselte a középkori keresztény etika, melyet például a skolasztikus filozófia is alátámasztott. Aquinói Tamás azon tételéból, mely szerint a testi munkára csak a végszükség kényszeríthet, a középkori egyházi értékelés a fizikai munka korlátozását emelte ki, mely tanaiban is így jelent meg. Igazát hangsúlyosan alátámasztotta például a kolduló rendek létezésén keresztül is. ${ }^{14}$

Ugyanakkor ezzel a megközelítéssel a munka szükségességének szerényebb rangot biztosított, mint a lelki gyakorlatoknak. Ez azt is jelentette, hogy az egyház hivatalos ideológiájában határt vont a vita activa, vagyis a dolgos élet és a vita passiva, a szemlélődő lét között ( utóbbi azt jelentette, hogy az ezt választó teljesen elfordult a földi világtól, hogy Istennek szentelhesse magát ). A lelki munka tehát teljes mértékben fölötte állt a kétkezi munkának. A hivatás és a kétkezi munka viszonyáról kialakított egyházi képpel kapcsolatban azonban az "alsóbb" rétegekben - különösen a parasztság és a polgárság körében - komoly változások történtek. ${ }^{15}$

\footnotetext{
${ }^{13}$ Fuchs, Walther Peter: Das Zeitalter der Reformation. In: Handbuch der deutschen Gesichte.

${ }^{14}$ Zarnecki, Georg: Kolostorok, szerzetesek, barátok. Budapest, Corvina, 1986. 106.

${ }^{15}$ Mezey B. i.m. 9.
} 
Luther teológiai-társadalmi felfogásában a munka isteni parancs, rendekre, állásra való tekintet nélkül. „Éppen elegendô a valóban szegényekról gondoskodni, óvni óket az éhenhalástól, megfagyástól, az nem történhet meg, hogy egyesek más munkájából, tétlenül éljenek." 16

Ugyancsak Luther szerint: a keresztény dolgozik, és rábízza a gondoskodást Istenre. „Ne légy lusta és tétlen, ne feledkezz meg tulajdon munkádról és tevékenységedrôl, hanem dolgozz és tégy is, ne mindent egyedül az Úrtól várj. Amint az gyakran mondva vagyon: mindennek Istenben való hitben és bizalomban kell történnie." 17 Ezen ponton kapcsolódott egybe hit és munka, ti. a hit és a munka összetartoznak, hit nélkül a munka vajmi keveset ér.

A fent értékelt protestáns tanítás szerint megállapíthatjuk, hogy a munka szerepe jelentôsen felértékelődött, ami például azt is jelenti, hogy az evilági élvezetek lehetségesek, de erre is csak a munka jogosít föl. Kálvin felfogása a legtöbb kérdésben közel áll Lutheréhez. Azon keresztül hogy a hit a munkát isteni szolgálattá tette, a minden közösségre hasznos, azt erôsítô tevékenység nagyobb elismerést nyert.

A reformáció, s különösen a kálvinizmus programmá formálta a szorgos munkálkodást, megkövetelte a tétlenség, dologtalanság elleni harcot, a szegénységet már-már a búnelkövetés fokára emelte. Luther úgy vélekedik errôl, hogy „aki szegény akar lenni, ne legyen gazdag, de aki a gazdagságot választja, annak nyomjuk kezébe az ekét, és keresse meg azt a földból". ${ }^{18}$

A fenti gondolattól eltekintve ugyanakkor alapelvként jelenik meg az is, hogy ha lehetséges mindenkit vissza kell vezetni a társadalomba és a közösség szorgos tagjává kell tenni (amihez megint csak a legkézenfekvőbb segédeszköznek a munka látszott). Ez társadalomszemlélet szintén óriási változás (és pozitívum) a korábbi elvekhez képest, amelynek világos, a máig ható érvénye van: a munka és a társadalomba való visszatérés között szerves kapcsolat áll fenn. Természetesen abból a tézisból kiindulva, hogy a koldust tilos segélyezni, a valóságos rászorulóknak viszont joguk van a segítségre, azt is jelentette, hogy a munkaképes nincsteleneknek munkalehetôséget kellett felkínálni. Azaz nem volt lehetséges pusztán az anyagi juttatásoknál megmaradni, a szegénysegélyezés más formáit is fel kellett használni, vagyis a naturáliákkal való segélyezés keretében a munkáltatásról is gondoskodni kellett. ${ }^{19}$

Azonban nem volt elegendô önmagában a munkalehetôség felkínálása, a teljes körú szegénygondozás részét kellett, hogy képezze a lelki gondozás és a nevelés is, amely egyrészt a rászorulóban felkeltette a hit iránti érdeklődést, másrészt fel-

\footnotetext{
${ }^{16}$ Laum, Bernhard: Armenwesen. Geschichte der öffentlichen Armenpflege. In: Handwörterbuch der Staatswissenschaften. Hrsg. Ludwig Elster, Adolf Weber, Friedrich Wieser (Redaktion: Dieter Werkmüller). Jena, Verlag von Gustav Fischer, 1923-1929. Band. I. 944.

${ }^{17}$ Conze, Werner: Arbeit. In: Geschichtliche Grundbegriffe Historisches Lexikon zur politischsozialen Sprache in Deutschland. Hrsg. Otto Brunner, Werner Conze, Reinhard Kosseleck. Stuttgart, Ernst Klett Verlag, 1974-1984. Band. I. 163.

${ }^{18}$ Idézi Laum i. m. 944.

${ }^{19}$ Mezey B. i.m. 17.
} 
ismertette vele a szorgalom és a munka iránti igényt. Külön figyelmet kapott a szegénység szélesedésének gyakori útja az elszegényedés, mely ellen annak megelözésével igyekeztek harcolni. Mindezek érdekében létrehozták a szegénygondozás szociális szervezetét, közösségi egyesületeit, gondoskodni kellett a házi szegényekrôl.

Azonban nem volt elegendő önmagában a munkalehetőség felkínálása, a teljes körü szegénygondozás részét kellett, hogy képezze a lelki gondozás és a nevelés is, amely egyrészt a rászorulóban felkeltette a hit iránti érdeklôdést, másrészt felismertette vele a szorgalom és a munka iránti igényt. Külön figyelmet kapott a szegénység szélesedésének gyakori útja az elszegényedés, mely ellen annak megelözésével igyekeztek harcolni. Mindezek érdekében létre hozták a szegénygondozás szociális szervezetét, közösségi egyesületeit, gondoskodni kellett a házi szegényekrôl.

„A skolasztika világ-és társadalomképével való teljes szakitás a protestáns munkaerkölcsben átfogóan végbement, ami a szúkölködést és tömegnyomort, mint a búnös világ örök, Isten által elrendelt büntetését fogadta el, és ezzel szemben a középkori emberiség elképzelhetetlen, tömeges elszegényedésének enyhitésére semmi mást nem ismert, mint az alamizsnát kéregető koldusok és az alamizsnát ajándékozó gazdagok örök, lemondó mozdulatát. Ez új, hideg és éles fény a kolduló létet magasztaló dicsfény helyett, amiben a zwingliánus és elöször igazán a kálvinista megtanulta életét irányítani, nem a nyomorúságnak, mint a bún bérének alázatos elfogadása, hanem a fegyelmezett munka jellemnevelése által” /H. Lüthy/20

\section{A koldulás elítélése}

A koldulást érintô gondolatkör lényege, hogy az Istennek tetszô aszketikus életvezetés és a hivatás során végzett hasznos cselekvés, a gyarapításhoz vezetô munka lehet az a tényezô, mely a bưn fölötti gyôzelmet jelentheti. „A munka ugyanis a sajátos megelôzési eszköz minden olyan kísértés ellen, melyet a puritanizmus a 'tisztátalan élet' fogalmában foglalt össze. A munka azonban ezen túl, s mindenekeloott az életnek Isten által megszabott öncélja. A páli mondat - 'Aki nem dolgozik, ne is egyék' - feltétlen érvényü és mindenkire vonatkozik. A munkakedv hiánya a kegyelmi állapot hiányának eleje."21

Ennek egyenes következménye viszont, hogy ha a munka ilyen kiemelt szerepet játszik az üdvözülésben, a munkakerülést is ennek megfelelően kell értékelni. A semmittevés elítélése Luthernél és Kálvinnál is a tétlenekkel szembeni harcig vezet el. „A legfontosabbak egyike felszámolni a koldulást a kereszténységben”. 22 A koldulás pedig megengedhetetlen. „Semmiféle koldust vagy koldulást ne tưrjünk meg városaink és falvaink templomaiban."23

\footnotetext{
${ }^{20}$ Herbert Lüthy: Calvinisme et capitalisme, Cahiers Vilfredo Pareto, Nr. 2. Genf, 1963.

${ }^{21}$ Weber, Max: A protestáns etika és a kapitalizmus szelleme. Budapest, Cserépfalvi, 1995. 188-189.

${ }^{22}$ Idézi Laum i. m. 944.

${ }^{23}$ Conze i. m. 163.
} 
Ez természetesen ekkorra kezdi azt jelenteni, hogy ha maga a koldulás elvetendő, ezzel párhuzamosan ítélendő el az egyház kolduspolitikája is. Éppen ezért a reformáció következetesen lépett föl a koldusok, az alamizsna és persze az ezekkel nagyfokú hasonlóságot mutató önkéntes szegénységgel szemben. Azokban a tartományokban, amelyek a reformáció útjára léptek a „keresztyéni szegénységet”, a mások adományából való élést elítélték, és a koldulás ettól kezdve a társadalom szemében deviáns magatartásként, de mindenképpen nemkívánatos jelenségként túnt föl.

Luther és Kálvin teológiai rendszerükben az általános keresztyéni életcélt összefüggésbe hozták a munkakötelezettséggel. Ez megközelítés a munkát a keresztyénség szerves elemévé tette, viszont ily módon a munkakerülésben, csavargásban magának a sátánnak a közrejátszó hatását látták. A koldulást szigorúan tilalmazott dolog volt, és a protestáns etika szerint a felebaráti szeretet ellen való magatartást jelentett. Ezen szemlélet hatására a koldus ellenséggé vált, bünözôvé, de mindenképpen a keresztény értékrend ellen vétő figurává. ${ }^{24}$ Ezzel a protestantizmusnak lerombolta a középkori etika pozitív viszonyát a kolduláshoz, azonban megállapíthatjuk, hogy ennek megszüntetése nélkül elképzelhetetlen lett volna a hirtelen megnövekedő szegénység kezelése, de talán még fontosabbként egy korszerû szegénygondozás kiépítése.

\section{Zwingli (Zürich)}

Ulrich Zwingli svájci (zürichi) reformátor, teológiai, egyházi tanai a németországi reformátorok tanaival jórészt egyeztek (egyes pontokban voltak köztük eltérések is), az ô reformációs megközelítése is meg akarta változtatni a diakóniához való hozzáállást, így az teljesen új alapokra helyeződött. Zwingli is a hit által való megigazulást hangsúlyozta és teljesen elvetette az érdemszerzó jócselekedeteket (amivé a diakónia végzése már kezdett válni). Viszont ugyanakkor a hívók egyetemes papságát hangsúlyozta és ezáltal azt, hogy mindenkinek ki kell venni a részét az egyház életéból és szolgálatából is.

Lutherhez hasonlóan azt is hirdette, hogy az egyháznak nem azzal kellene hitegetnie magát, hogy diakóniát végez, ha a Szentírást olvassa, hanem az egyház kincseit kellene szétosztaniuk a szegények között. A diakonátust is újra akarta szervezni, azonban nem egy külön egyházi szerv létrehozásával, hanem úgy, hogy a keresztyén vezető réteg feladata legyen a diakónia. Minden keresztyén ember kötelességét hangsúlyozta ebben, mégis tőlük várta azt, hogy igazán felvállalják ezt a szolgálatot.

Luther indítására sok német város tanácsa választott egy képviselőt, akinek a szegényekról való gondviselés volt a feladata, aki látogatott, számon tartotta a szegény családokat és próbált valós szükségletfeltárást végezni (természetesen az ilyen

\footnotetext{
${ }^{24}$ Mezey B. i.m. 12.
} 
képviselök nem beiktatott diakónusok voltak). Ehhez hasonlóan Zwingli is a tanács feladatává tette, hogy szegénygondozó bizottságokat állítsanak fel, melyek gondozóból és egy elöljáróból álltak és ő egyáltalán nem gondolt arra, hogy a diakónusi tisztet újra fel kellene állítani.

Egyháztanában Zwingli puritán, civil egyházat kívánt teremteni, amely elválaszthatatlan az állami, a társadalmi közösségtól, feladatai pedig a morális és szociális gondoskodásra is kiterjednek. A jobbágyság megszüntetését és számos szociális gondoskodás bevezetését neki köszönhetik honfitársai. Korai halála miatt gondolatai a kálvini reformációba épültek be.

\section{Bucer (Strassbourg)}

Martin Bucert (1491-1551) Strassbourg reformátorát, a városban uralkodó nyomor, a menekültek megsegítésének vágya és önnön helyzetének nehézsége a szegénygondozás bibliai alapokon nyugvó megszervezésére ösztönözte. ${ }^{25}$

A strassbourgi reformátor volt az, aki „Az igazi lelkigondozásról” írt munkájában az összes egyházi szolgálatnak a lelkigondozás szempontja alatt való tárgyalását adta, melyben az ApCsel 6. és az 1Tim 3. részekre alapozva szállt síkra a gyülekezeti szeretetmunka bevezetéséért: „Ezekból a szentírási helyekból azt tanuljuk meg, hogy az egyházak tevékenysége minden idóben kétféle szolgálatból állt: a lelkekkel való törôdésból és a nélkülözókról történó gondoskodásból. Mindkét munka végzóit a legelsố idóben apostoloknak, majd diakónusoknak nevezték . . . Milyen hivatal vagy tisztség volt ez és milyennek kell lennie ma is e munkának, amelyre a keresztyének a vasárnapi összejöveteleken és más alkalmakon pénzt hordanak össze és áldozatot hoznak a nincsteleneknek eltartására? Amit egyes személyek az alsóbb és felsóbb rendból adnak erre a munkára folyamatosan, a hüséges Isten parancsa. "

Az igazi lelkigondozás az Úr Jézus szentjeit legelteti s választottjait bűneikból a hit által való megigazulás útjára vezeti, Isten igéjének prédikálása és az evangélium fegyelme által, a hivôt Krisztussal összekapcsolja s az ô hatása és uralma alá helyezi. A lelkigondozás megkeresés és megtartás.

A pásztor feladata, hogy Krisztus juhai mindent megkapjanak, amit Ô igéjében ígér nekik. A vétkezóket és elesetteket igaz megtérésre segíti. Az ingadozókat a hitben és életben támogatja, segíti. Vannak elveszett, eltévedt, megsebzett, erôtelen és erôs juhok: mindegyikkel a maga természete szerint kell bánni. Tudatlanság, hamis ismeret, hamis istentisztelet, cselekedeti és mulasztási bûnök, kishitûség, restség, közönyösség lehetnek a tipikus akadályok.

„Az igazi lelkigondozás” summájában így ír Bucer: „Ilyenképpen szolgálhatjuk hiven az Urat: a törvényes rendnek megfelelöen válasszuk meg és iktassuk be a társadalom minden rétegéból származó lelkészeket. A cél az, hogy olyanok legyenek ók, akikben mindenki megbizik, és akiket mindenki szeret, akik e szolgálatra

\footnotetext{
${ }^{25}$ Ifj.Dr. Fekete Károly: Kálvini reformáció és diakónia 2007. március Református Szeretetszolgálat II. évf. 1.szám 2.
} 
és igazi pásztori gondoskodásra kellő talentumot és buzgóságot kaptak. Ily módon teljesül a pásztori gondoskodás öt feladata: az elveszettek felkutatása és megtalálása; a szétszórattak visszahozása; a sebesültek gyógyítása; a betegek megerósítése; az egészségesek védelme és legelöre vezetése." Ennek a felfogásnak a jó pásztor uralkodásáról szóló Ez 34,16kk adják a bibliai alapját. A lelkigondozás fô eszköze az igehirdetés, amely nem korlátozódik csupán a szószékre. Történnie kell házanként és minden elképzelhető módon. Egyházi szolgák és egyháztagok lelkigondozói munkája összefonódik.

Bucer világosan képviseli, hogy a Krisztus egyháza szervezett keresztyén társadalom is, amelynek befelé és kifelé missziói küldetése van és ez az egyház mindenkinek minden testi-lelki szükségérôl való, mindenki által gyakorlandó gondoskodást jelent. A hitból fakadó szeretet karitatív, szociális és erkölcsi tevékenységre indít a közösségben. Bucer a teljes emberre tekintett, annak testi-lelki szükségeivel, külsôbelsố problémáival, s nála egymásra talált a lelkigondozás és a diakónia. ${ }^{26}$

Bucer másik múvében - De regno Christi - 1550-ben azt tanította a szegénygondozásról, hogy abban Isten egyik fó parancsát teljesíthetjük, mert az Úr megtiltotta népének, hogy elnézze akárcsak egyetlen tagjának is a nélkülözését (5Móz 15,4). Ennek a parancsnak lett a következménye, hogy a jeruzsálemi gyülekezet minden tagja részesült a felajánlott ajándékokból a becsületes és istenféló élethez szükséges módon.

\section{A szegények, a szegénygondozás Kálvin szociáletikájában}

Ezt a nagyon érdekes területet - mi volt a kor egyik legnagyobb reformátorának a megközelítése, a meglátásai a vizsgált területtel kapcsolatban, aki ráadásul ezeket a ( nagy részt azóta is múködô ) szemléletbeli újításokat, elveket teológiai rendszerbe is foglalta - Prof. Dr. Fazakas Sándor tanulmánya ${ }^{27}$ alapján dolgoztam fel, mert azt megismerve úgy éreztem, hogy az itt kibontott kérdéseknek dolgozatom témája szempontjából is központi jelentősége van.

A gazdag ifjúról (Mt 19,16-26) szóló példabeszéd magyarázatával Kálvin megújítja az egyház szociális tanítását. Érvei között a legfőbb, hogy sehol nincs a törvényben parancs arra, hogy adjuk el mindenünket, hiszen ,a vagyontól megválni magában még nem volna erény, hanem inkább dicsekvô hiúság"28, ui. Krisztus nem egyszerúen a vagyontól való megválást, hanem azzal a szegények megsegítését követeli meg.

Kálvinnak a szegénységról szóló teológiai gondolatait az 1555-56-ban tartott de-

\footnotetext{
${ }^{26}$ Fekete i.m. 3 .

${ }^{27}$ Dr. Fazakas Sándor: Kálvin szociáletikája in: Kálvin idôszerûsége-Tanulmányok Kálvin János teológiájának maradandó értékéról és magyarországi hatásáról ( szerk.: Dr. habil. Fazakas Sándor ) Magyarországi Református Egyház Kálvin János Kiadó Bp., 2009.

${ }^{28}$ Kálvin János magyarázata Máté, Márk és Lukács összhangba hozott Evangéliumához.III. kötet, ford. Rábold Gusztáv, Budapest 1941, 137-138. Idézi: Dr. Fazakas S.
} 
uteronómiumi prédikációiból ismerhetjük meg, közelebbról az 5Móz 15,11-15 alapján tartott igehirdetéséból, amelyben kritika alá veszi a középkori ember azon felfogását, mely - "mert a szegény nem fogy el a földról" (5Móz 15,11) - a szegénységet Isten által adott és megfellebbezhetetlen rendként fogta fel. Kálvin ezt a bibliai részt nem a kialakult szociális helyzet fenntartásaként, hanem Isten végzésének bizonyítékaként tekint. Eszerint a szegénység világban való jelenléte nem fatalista életszemléletre vagy tehetetlen beletörôdésre kell hogy vezessen, hanem annak leküzdésére.

A gondviselésről szóló tanítás tükrében Kálvin olyan teológiai megoldást talál, amely a szegényt és a szegénységet az Istennel és a gazdaggal való kapcsolatában veszi figyelembe, vagyis a gazdagnak és a szegénynek egyaránt Isten az ura. Ezért a gazdagnak látnia kell, hogy gazdagsága Istentól való, így gazdagságát nem tekintheti a másik ember feletti hatalmi eszközként. Isten ugyanakkor a gazdag hitét is próbára teszi: mennyire képes a felebaráti szeretetet a szegénnyel szemben megélni? A szegény próbája viszont, hogy sorsát türelemmel kell viselnie (nem teheti meg például, hogy rablással vagy csalással javítson helyzetén). Természetesen Isten mindkét oldal helyzetét megváltoztathatná, de nem teszi, mert a hit iskolájában kívánja belátásra vezetni a szegényt és a gazdagot is.

Kálvin e pedagógiai megoldással régi keresztyén hagyományt tartja, viszont a szegénység nála továbbra is az isteni gondviselés kiismerhetetlen titka marad, amely a helyes istentisztelet és a gyakorlati keresztyénség kulcskérdése. A szegény és a gazdag a gondviselés jegyében egymásra vannak utalva, ugyanis a szegényt Isten küldi maga helyett a gazdag felé, de ez a találkozás a gazdag számára már az élet értelmérôl és az örök életről szól, ezért a gondviselés és üdvösség felól tekintve a gazdagnak szinte nagyobb szüksége van a szegényre, mint fordítva. (Például a koldulás eltûrése, azon túl, hogy a fennálló állapotot szentesítené, a fent leírt rend negligálása.)

Emellett fennáll a veszély, hogy a szegényekrôl való gondoskodás a „szegénykérdés objektivizálódásához"29 és osztály-, illetve rangkülönbségek kialakulásához vezet. Ezért hangsúlyozza Kálvin a szegényekról való gondoskodás személyes elkötelezettségét az Írás alapján, hiszen nem általában vannak szegények, hanem mindannyian a te szegény testvéreid (5Móz 15,9.11). Ez a gazdag és a szegény kapcsolatának már olyan dimenziója, amelyben e kapcsolat élő organizmusként tekinthető, communióként ${ }^{30}$ a szó szoros értelmében, s amelyben „lelki csoda” megy végbe, ami már az élő hit konzekvenciája.

A nagy reformátor atya szerint a földi javak végsố soron Istentől kölcsönkapott javak, amelyek tulajdonjoga személyekhez kötött ugyan, de amelyek a felebarát és a közösség hasznát és az emberek közötti békét kell, hogy szolgálják. Az 5Móz 24,19-22-rôl szóló prédikációban Kálvin az eddigiekhez hasonló logika mentén foglalja össze mondanivalóját a szegénykérdésrôl:

\footnotetext{
${ }^{29}$ Scholl: Die Kirche und die Armen in der reformierten Tradition.In: Reformierte Kirchenzeitung( RKZ ) 124, 1983. 68. Idézi: Dr. Fazakas S.

${ }^{30}$ Communio: a gazdag és a szegény közötti közösség. Dr. habil. Fazakas Sándor, I.m. 128-129.
} 
„1. Isten azért bizta a földi javakat a gazdagokra, hogy azok a szegényeket is részeltessék a jólétben. A gazdag és a szegény kölcsönösen egymásra van utalva mind az Isten szine elôtt, mind pedig a keresztyén gyülekezetben.

2. A kölcsönkapott javak a gazdagokat Istennel és a szegényekkel szövetségbe vonják, ugyanakkor hálaadásra köteleznek. Ez az isteni jogrend az emberi jogrendre nézve azzal a gyakorlati következménnyel jár, hogy a szegény ne akarja erốszakkal megszerezni magának a javakat, de a gazdag részesítse benne a rászorulókat.

3. A gazdag különösképpen ki van téve a hálátlanság, a kapzsiság és az önistenités kisértésének; ez Kálvin szerint bün, amely felett akkor lehet úrrá az ember, ha a földi javakat Isten áldásának tekinti.

4. Az istenképú emberek (szegény és gazdag egyaránt istenképü) keresztyén gyülekezetben megvalósuló közössége a communio sanctorum ígéretét hordozza. Ez az aktuális társadalmi helyzet elemzésén és az eljövendő közösség reménységén túl a múltra való emlékezés kötelezettségét is magában foglalja: az exodus, a szövetségkötés és a honfoglalás történetében a gazdag mint megajándékozott, a szegény pedig mint a megmentett ismerhet önmagára. 5. Végül is mindketten, a gazdag és a szegény egyaránt a kegyelemre ráutalt emberként áll Jézus Krisztus színe elótt - igazi humanitás az emberré lett Isten kijelentésének meghallásából fakad. "31

Kálvin szegénység-gazdagság kérdésében is egyfajta megfeleltetést mutat: Isten embersége és az ember humanitása, Isten bókezúsége és a szegények javakban való részeltetése, az Isten irgalma és az ember embertárs iránti könyörülete között. Kálvin nem próbálkozik idealisztikus társadalmi modell felállításával; reálisan látta a gazdagok ellenállását, általa kora főbúnének tartott kapzsiságát, hogy a gazdagság az embert helyes önismeretében gátolja. Másrészt a szegénységet sem eszményíti vagy spiritualizálja. ugyanolyan keményen inti a szegényeket is, mint a gazdagokat. Viszont a felebaráti szeretet megélésének konkrét és realisztikus lehetôségét szem előtt tartva a józan méltányosság (aequitas) és mértékletesség alapján követeli, hogy „mindenkinek megadassák a magáe”, tudva azt, hogy nincs nehezebb, mint a vágyakat megfékezni és ,a test indulatai által parancsolt dolgoknak búcsút mondani" 32

Teológiai-etikai megfontolásai és gyakorlati következtetései nem radikális, hanem közvetitő lehetôségek, amelyek az Isten igazságossága és az emberi élet valósága között igyekeznek közvetíteni.

\section{Kálvin strukturális változtatásai}

\section{A diakóniai tevékenység helye Kálvin egyházrendszerében}

Az elôzőek alapján több ponton levonhatnánk a következtetést, hogy Kálvin e teológiai gondolatvezetéssel nem az igazságtalan társadalmi viszonyok felszámolására,

\footnotetext{
${ }^{31}$ Ugyanott Dr. Fazakas S.

${ }^{32}$ Inst. III, 7,3 Idézi: Dr. Fazakas S.
} 
hanem azok új módon való vallásos legitimálására törekszik - fôleg miután int a szegénység forradalmi módon való felszámolásának kísérletétől. Ugyanakkor viszont felhívja a figyelmet szegénység megszüntetésének szociális dimenziójára: kórház, árva- és szegényház felállítását, illetve a szegénygondozás intézményi feltételeinek megteremtését követeli a várostól, illetve a szegények gondozását a keresztyén gyülekezet életrendjévé teszi.

Utóbbi a diakonátus intézményének átgondolását eredményezi, mely szerint különbség van azok között, akik az egyház javait (köztük a szegényeknek szánt adományokat) kezelték, ill., akik ,önmagukat a szegények és betegek gondozására szentelték". 33

A reformáció és Kálvin teológiájának tengelye Krisztus (solus Christus) és a Róla szóló bizonyságtétel, az Úr Jézus Krisztus három tisztérôl (munus triplex Christi: munus propheticum - a prófétai tiszt; munus sacerdotale - a papi tiszt; munus regium - királyi tiszt) szóló tanítás, aminek hatása volt a református gyülekezet-, és egyházszemléletre is. Ez aztán megjelent a presbiteri tisztról szóló tanításban is. Az Institutioban leginkább a II,15-ben, illetve a gyülekezeti tisztségekról a IV,3 8-9-ben olvashatunk ide vonatkozó gondolatokat. Kálvin tanításának hátterében az a bibliai és teológiai meggyôzôdés áll, hogy az egyházban egyedül Krisztus uralkodhat, ennek következtében az egyház múködésében, rendjében és feladat meghatározásában is a három tisztnek kell megmutatkoznia. Krisztus három vagy hármas tisztének, azaz a prófétai, a papi és a királyi tisztnek a gyülekezetben négy vezetôi feladat felel meg: a prédikátori, illetve tanítói hivatal, a diakóniai szolgálat és a presbiteri rend.

A Krisztus hármas tisztén nyugvó gyülekezeti/egyházi tisztségek gyakorlatba történô átültetését Kálvin az 1541-ben kiadott genfi egyházi rendtartásban kezdte meg. A négy feladatkörre, vagy hivatalra pásztorok, tanítók, presbiterek (=vének) és diakónusok - nézve a Genfi Egyházi Rendtartás világos körülhatárolást hozott. A diakónusok feladatai: kétféle szolgálatra is van megbízatásuk. Az egyik a szegénygondozás, azaz a nekik szánt adományok elosztása és kezelése. A másik a betegek gondozása. Ennek megfelelően Genfben voltak külön kórház-felelősök és gondozók is. A presbiterek Krisztus királyi tisztének felelnek meg, ók a vezetôk és lelkigondozók, de nem uralkodhatnak a nyájon, a gyülekezeten. A kereszten egyszer s mindenkorra bevégzett és elvégzett krisztusi papi szolgálatnak, hivatalnak, tisztnek a szegénygondozás, a diakóniai szolgálat felel meg. ${ }^{34}$

A diakónusi szolgálat kérdéseinek tisztázása, valamint a diakónusok választásának és feladatkörének alapos felvázolása is bizonyítja, hogy Kálvin a diakonátusnak az ekkléziológiában szerves szerepet szán. Csakis a négy tisztség (pásztorok, doktorok, vének, diakónusok) együttmunkálkodása által múködhet jó rendben az egyház - de diakonátus nélkül nincs ecclésia!

Kálvin veszélyként látja, hogy a diakónusok legkörültekintőbb kiválasztása és szolgálatba iktatása esetén is kiüresedhet a szolgálat, ha a tisztség viselói felada-

\footnotetext{
${ }^{33}$ Inst. IV, 3,9. Idézi: Dr. Fazakas S.

${ }^{34}$ Dr. Békefy Lajos (szerk.): Kálvin tanításai (IV.) Jézus Krisztusról (B.), www.reformatus.hu
} 
tuk lelki dimenzióit nem tudatosítják. Késóbb egy prédikációban így jellemzi ezen kérdés helyzetét: a szegényeket jóllakatjuk levessel, de közben megfeledkezünk az örömhírrool, az Evangéliumról. Az egyház diakóniája ugyanis gépies ,levesosztássá” laposodhat, ha elfeledkezik a szolgálat lelki dimenziójáról. ${ }^{35}$

Meg kell még említenünk, hogy természetesen Kálvin a reformáció diakóniai elveit alapvető́n ismerte, vallotta, de annak eredményességét nagyban segítette Bucer ezzel kapcsolatosan elgondolt gyülekezeti mintája. Strassbourgban Kálvin megalapította és megerôsítette az elsô szervezett menekült gyülekezetet, melynek szolgálatára diakónusokat képzett ki, akik segítségére voltak a lelkigondozásban, és gyámolították a szegényeket és a betegeket. A diakónusokkal rendszeresen tanácskozott, Szentírást olvasott és imaórát tartott. Kálvin strassbourgi számúzetése alatt tapasztalhatta Bucer lelkipásztori és lelkigondozói tevékenységének áldásait és maga is indíttatásokat kapott az atyai baráttól, emellett itt egy jól szervezett és rendezett gyülekezeti élettel ismerkedett meg, amelynek tapasztalatait később Genfben kamatoztatja.

A cselekvô hit a reformáció korában Isten gyermekének, testvérnek, a közösség tagjának tekintette azt a rászorultat, akinek adott, de szétválasztotta az egyház fenntartását és a szegénygondozást. Ezenkívül a cselekvő hitból törvényi garanciák is születtek, megmozgatta a közösséget (ebben az egyes tagok egyéni felelôsségükkel vettek részt), ezért mondhatjuk, hogy a hitból cselekvók utat nyitottak a nagyobb társadalmi változások felé is.

\section{A szociális kérdés Kálvin Genfjében}

Mi tekintheto Kálvin Genfében újnak és másnak, korával összehasonlítva a szociális és gazdasági feladatok területén? Kingdon szerint ebben a városban már a középkorban létezett szegénygondozás. A 16. században az volt ebben az újdonság, hogy ezt a munkát racionalizáltabbá tették és laikusok is végezték. ${ }^{36}$

Mark Valeri szerint Kálvin szemléletében a gazdaság és a közjó(lét) teljes harmóniában volt egymással. ${ }^{37}$ Kiváltképpen az uzsoráskodás ellen vette fel a küzdelmet, de nem vak radikalitással vizsgálta ezt kérdést, hanem teológusként, akinek van gyakorlati gondolkodása ahhoz, hogy különbséget tegyen a hitelnyújtás és az uzsora között. Alapvetően különbséget tett mérsékelten kamatozó kölcsön segítség (amit akár egyfajta prevencióként is szemlélhetünk!) és uzsora között, ennek igazolása természetesen meghatározott feltételekkel kerül összekötésre, amiket Kálvin „De l'Usure” (Az uzsoráról) címú írásában fejtett ki részleteiben. Ide tartozik az a nézet, hogy a kamatláb megállapítása nem egyesek ügye, hanem az egész társadalomé, vagy fontos kitétel például, hogy a hitelt nyújtó nem követelhet sokkal

\footnotetext{
${ }^{35}$ Fazakas S. i.m. 127.

${ }^{36}$ Eberhard Busch: "Isten számára lehetetlen, hogy ne legyen irgalmas hozzánk ..." Töredékek Kálvin etikájáról A KDNP PM Tanulmányi Füzetei II. Kálvin társadalmi reformgondolatainak időszerűsége Kiadja: KDNP - Protestáns Múhely 32.

${ }^{37}$ Uo.
} 
többet, mint amennyit maga fizetett, ill. a haszonból le kell vonni az irgalmasság szükségszerúségeire is. Összességében pedig egyáltalán nem lehet kamatot követelni, ha az okozta a kölcsönző gazdasági csődbe jutását.

Mivel az uzsora újra és újra felbukkant, csak más és más formában, Kálvin küzdelme a beszéd megbízhatóságáért is folyt annak hamis használata ellen és elkötelezett híve és gyakorlója volt a szociális szolidaritásnak. Valeri Kálvin szemléletét úgy jellemzi, hogy megfogalmazza, mi ellen is irányult Kálvin igyekezete: „A kommunikáció kötelékeinek feloldása az egyéneket elszigeteli egymástól a szociális együttélésben és a felebarát kihasználásához vezet, mint aki az egyéni haszon, profit megszerzésének puszta eszközévé vált". ${ }^{38}$ Egy másik szerzô, Jane Demsey Douglass ezt írja: Kálvin szerint „a meggyógyult humanitás nem individuális, hanem szociális"39.

Minden embert egyenlonek teremtett Isten egymással, és egymás számára teremtette oket. Ha pedig valaki ez ellen a teremtettségbeli meghatározottság ellen fordul, akkor az a bünnek a kifejezett jele és Isten haragját vonja maga után. Kálvint a személyes felelosség érdekli, de ezzel összefüggésben és egyszerre a szociális, közösségi szolidaritás is. És az is nyilvánvaló, hogy Kálvin egyezést lát a Krisztus testén belüli kölcsönösség, s aközött, amit látni szeretne a politikai irányítás, a városi tanács tagjai és az egyházi presbiterek között a nyilvános vagy közfelelosség területén.

Két formája volt a szegénységnek és a nyomornak, ami Kálvin véleménye szerint a városi együttélést a vizsgált korszakban különösen zavarta és a személyes felelosséget, a szociális szolidaritást próbára tette.

Az egyik, ahogyan a helyi lakosság az idegenekhez viszonyult (ebben az idóben sok francia menekült érkezett a városba, maga Kálvin is valójában élete végéig idegen maradt Genfben): dönto problémává lett, hogy az idegeneket valóban felebarátaiknak tekintik-e a genfiek.

Kálvin a Mózes 5. könyvérol tartott egyik igehirdetésében beszélt találkozásáról az egyik idegennel és ezt írta: Jóllehet nem tudtunk egyetlen szót sem váltani egymással, „Urunk mégis megmutatta ma nekünk, hogy testvérek lehetünk, mert Krisztus az egész világ és a föld összes lakójának a békessége. Ezért testvéri közösségben kell élnünk egymással, amit Krisztus saját vérével alapított meg. És minden ellenségeskedéssel (amivel csak találkozunk) lehetoséget nyújt nekünk arra, hogy ellenálljunk az ellenségeskedésnek". 40

A másik nagy nyomorúság, amire Kálvin tanítóként és prédikátorként a genfiek figyelmét felhívta, a szegények és a gazdagok között fennálló szembetuno és bántó különbség. Kálvin a középkorban jellemzô szegényekkel kapcsolatos gondolkodással ( ld. fent ) szemben úgy ítélte meg, hogy a szegénység égbe kiáltó botrány. A szegénységnek ilyen elképeszto formájára tekintettel Nicholas Woltersdorff Kálvin

\footnotetext{
${ }^{38}$ M. Valeri, Religion, Discipline, and the Economy in Calvin's Geneva, in: Sixteenth Cenury Journal XXVIII/1 (1997), $137 \mathrm{f}$.

${ }^{39}$ J. Demsey Douglass, Calvin's Relation to Social and Economic Change, in: Church and Society, March/April 1984, 127.

${ }^{40}$ Calvin, Sermo 125 zu Deutr. 22,1-4, CO 28, 16 f., Valeri, 139.
} 
gondolatait egy mondatban így foglalta össze: „A szociális igazságtalanság és a szociális áldozatok könnyei sértik, bántják Istent". ${ }^{41}$ Azt, hogy az emberek Isten képére lettek teremtve, véleménye szerint Kálvin úgy értelmezte, hogy Isten önmagát úgy látja, ismeri fel bennünk, mint áldozatoktól gyötört embertársakban. Ám éppen Istennek ebben a megsebezheto szeretetében nyer megalapozást az igazságosságért folytatott küzdelem.

Ezért Kálvin szerint a gazdagok feladatukat nem tudhatják le az alamizsnálkodással, hanem, amint Valeri Kálvint idézi: „Nem tudom elszakítani magamat azoktól, akik szükségbe kerültek, akikkel Isten összekötött engem." ${ }^{2}$ Ebból a szolidaritásból nézve, pont fordított a helyzet: a gazdagok luxusát a nagyvárosokban kell igazi égbekiáltó botránynak tekinteni. Ez a luxus az önzés kifejezodése, amint azt Kálvin az elsô Korinthusi levélhez írott kommentárjával bizonyítja. Ha Kálvin tanítása a megszentelôdésrôl Institutioja szerint az önmegtagadásról veszi a példát, akkor először innen nézve értjük meg, hogy ezzel nem valamiféle önmagában értékes dolognak tekinti a szegénységet, s nem is valamilyen életörömre való képtelenségból jut erre a gondolatra (még akkor is, ha az életöröm sokféle betegség következtében nem jelent meg Kálvin arcán). ${ }^{43}$

Kálvin felelősségvállalása a szociálpolitikában a társadalom és az egyén kiegyensúlyozásáért teljesen az ellenkezô irányba tartott, mint Adam Smith klasszikus kapitalizmus elméletében, miközben a lutheránusok azt vélik, hogy ez támadás az isteni rend szent fundamentuma ellen. Így vélekedik az újabb idoben Gamble vagy Reid is: „A genfi kálvinizmus inkább volt támadás a gazdagság ellen, mint a tôkefelhalmozás védelmezése".44 Wolterstorff idéz Kálvinnak egyik prédikációjából, amit a Galata 6,9-11 alapján tartott, ahol mind a szegényeket, mind az idegeneket együtt szemléli, és ezt mondja: „Saját arcunkat nem láthatjuk a tükrön kívül másban, mint azok személyében, akik szegények és lenézettek . . . és így mintha a legtávolibb messzeségbol érkezo idegenek lennénk ezen a világon. Ha beengedünk közénk egy feketét vagy barbárt, idegent, s mivel o is ember, magával hoz egy világos tükröt, amiben megláthatjuk, hogy o a testvérünk és a felebarátunk". ${ }^{45}$

Ez a lelki-szellemi felismerés a gyökere Kálvin érdeklődésének a szociális és gazdasági kérdések iránt. Ezért írta a 2Kor 8,13kkhoz készített magyarázatában, amire már André Biéler is utalt: „Isten azt akarja, hogy kapcsolatban álljunk egymással és egyenlókként nézzünk egymásra, azaz hogy mindenki el legyen látva a szükségessel eszközeinek mértéke szerint, mégpedig úgy, hogy senkinek se legyen túl kevés vagy túl sok semmiból". 46

\footnotetext{
${ }^{41}$ N. Wolterstorff, The Wounds of God: Calvin's theology of social injustice, in: The Reformed Journal, Juni 1987, 14-22.

${ }^{42}$ Calvin, "Argument" zum Kommentar zum ersten Brief von Paulus an die Korinther (1546/1556), Edinburgh 1960, 6 ff., 12 ff. (CO 49), cf. Valeri, 137.

${ }^{43}$ Eberhard Busch: I.m. 33

${ }^{44}$ S. Reid, John Calvin. Early Critic of Capitalism (1), in: The Reformed Theological Review, 77-79, und R.C. Gamble, ebd., 161-163.

${ }^{45}$ Wolterstorff, 138f., = CO 51, 105.

${ }^{46}$ CO 50, 100f.; A. Biéler, The social Humanity of Calvin, trans. by P.T. Fuhrmann, Richmond 1964, 33, vollständiges Zitat im Vorwort von Visser't Hooft, 8.
} 
„Isten azt akarja” - fogalmaz ezzel a fordulattal Kálvin. Ô ezt az Isten Igéjének a prédikátoraként mondja. Ezt keresztyén gyülekezetben mondja, s ennek a gyülekezetnek úgy kell értelmeznie önmagát, mint olyan közösséget, ahol az emberek egymással is közösségben vannak, és személyes felelôsséget viselnek egyetlen fejük, Krisztus fôsége alatt egymásért is.

Kálvin tehát úgy tekint az állami területre, mint olyan berendezkedésre, ami azért jött létre, hogy a közjóért és szabadságért álljon fenn, s olyan módon legyen a közjó ápolója, hogy ne károsítsa a szabadságot, meg hogy ne a közjó kárára valósítsa meg a szabadságot. De Kálvin erről úgy szól, mint aki a Biblia magyarázója, prédikációkban és írásmagyarázati kommentárokban, mivel ô nem a maga egyéni ízlése szerint használta a Szentírást, hanem az Istentôl hitelesített igét akarta komolyan venni az akkori jelennek szóló üzeneteivel. Az igét Isten nevében mondta, prédikálta, aki Kálvin számára nem valamiféle diktátor, hanem, amint megmutatta magát Krisztusban, az a magasságos, aki a legkisebbeket is vállalja. ${ }^{47}$

Randall Zachman Kálvin-munkájában („Kiáltás Istenhez a kétségbeesés szélérôl") ír Kálvin zsoltármagyarázatairól is, így a 22. Zsoltár ezen mondatához írt megjegyzésérôl is: „Én Istenem, miért hagytál el engem?”. És a genfi reformátor azt írja ezzel kapcsolatban, hogy mi - nem önmagunkra tekintettel, hanem az Istenre felnézve, annak biztos tudatában kell lennünk, hogy „Isten irgalmas hozzánk, még akkor is, ha néha úgy túnik, ellenünkre van". Ehhez még a 77. Zsoltár panaszához írt mondatára is érdemes odafigyelnünk: vajon Isten elfeledkezett volna arról, hogy irgalmas? Kálvin válasza: „Isten jó volta elszakíthatatlanul összekapcsolódik lényével, mivel lehetetlen számára, hogy ne legyen irgalmas ...".48

\section{A református szegénygondozás új rendszere}

A protestáns felfogás egyértelmúvé tette, hol a határ a közösség segítségére valóban rászoruló szegény és a munkakerülő között, ez a forradalminak nevezhetô változás pedig lehetôvé tette a szegénygondozás új modelljének kialakulását.

Rendszerszerúen kezdték kiépíteni a protestáns területeken a szegények hivatalos támogatásának és munkáltatásának szervezeti kereteit, eközben következetesen elutasították az alamizsnarendszert. („A könyöradomány nem jótett.”49) Ezekben a térségekben megszünt az a szempont, mely az alamizsnát tekintette az üdvözülés eszközének, melynek helyébe a felebaráti szeretet lépett. Önmagában nem azzal tudunk segíteni a szegényen, hogy lemondunk vagyonunk egy részéról, s pusztán ez a tett már erkölcsi értékkel bír - tanították a protestáns ideológusok. A segítség akkor valódi, ha a segélyezett saját erejére is támaszkodik.

Ez a meghatározás a hatóságoktól is új gondolkodást igényelt, hiszen azt mindenki értette és látta, hogy a koldusok, szegények nem egyazon okból váltak azzá.

\footnotetext{
${ }^{47}$ Eberhard Busch: I.m. 34.

${ }^{48}$ Randall C. Zachman, Crying to God on the brink of despair: The assurance of faith revisted, in: Calvinus Praeceptor, 351-358, hier 355f.

${ }^{49}$ Weber i. m. 196.
} 
Nyilvánvalóvá vált tehát, hogy a szegények nem önhibájából rászoruló csoportjára nézve át kell alakítani a gondoskodás rendszerét. Azonban, ha az egyházi jótékonykodás eredeti formáját felszámolják, ill. egyes csoportoknak a segélyezésre való jogosultságát elismerik, az a gondozási kötelezettség megállapítását és telepítését is feltételezi. ${ }^{50}$

Elvetendő és meg nem engedhetô koldulásnak számított az egészséges, munkaképes felnôttek koldulása, ez nyilvános szemrevételezést követelt. Az eljárás során megvizsgálják a koldus testi állapotát (szükség esetén orvosi szakvéleményt is igénybe véve), és akikrôl ily módon kiderül, hogy "betegségük" lustaság, azokkal szemben intézkedni kell. Ezzel mindenki számára egyértelmúvé akarták tenni a „rossz” koldusság elítélendő mivoltát. Érdekes jellemzóként elmondható, hogy a teóriát oly hamar követte a gyakorlat, hogy Stralsoundban ez a vizsgálati rendszer ebben az idôben már a napi (heti) gyakorlat részévé vált. Ez azt jelentette, hogy aki segélyhez szertett volna jutni, annak hétfőnként meg kellett jelennie a Miklós templomban, itt egy bizottság tagjai alaposan szemügyre vették, tájékozódtak személyes viszonyai felől, s ha egészségesnek és munkaképesnek találták, bizony „Zsákmány” nélkül kellett távoznia. ${ }^{51}$

A valóban rászorultak segélyezése tehát alapelvvé vált, viszont azt figyelembe véve, hogy aki munkaképes, dolgozzék, aki viszont nem, azt közössége méltó és tisztességes módon lássa el, gondozza. Nem változtattak tehát a korábban kialakult gyakorlaton a közösség kötelezettségével kapcsolatban, vagyis egyértelmúen a közösség (a város) gondoskodott a betegekrôl, nyomorékokról, öregekról, zavart elmeállapotú, stb. polgárairól. Hosszú ideig fennmaradt viszont még a saját és idegen szegénység kettôssége, melyet éppen a gondozás közösségre koncentráló iránya tartott fenn, ez jellemző a tartományi szegénypolitikára is, jóllehet ott kevesebb eséllyel tudták az ellenőrzést megszervezni.

A közösségi szegénygondozás átalakításának három alapelve volt (ezek többnyire ki nem mondott, nem deklarált, de meghatározó szempontok voltak). A legfontosabb, hogy az addig ,elfecsérelt eszközöket” egyesíteni kell, és „az esetleges vagy összefüggéstelen segélyezés helyett szabályozott gondoskodással szolgálja a valóban rászorultakat". 52

Mint az idézetból is kitúnik, az elsô alapelv a szabályozott, ellenôrzött és koncentrált forráskezelés technikai megoldásáról szólt. A közösségi persely bevételét, amelybe minden létezô támogatást, segélyeket, alapítványi összegeket, adományokat belehelyeztek, alkalmi gyújtések, lottériajátékok bevételével egészítették ki. Emellett ide került a volt egyházi vagyon egy része is, továbbá a laikus testvérségek pénze is. A városok vezetôi abban bíztak, hogy ez az összeg elegendô lesz a majdani felmerülő igények kielégítésére. A persely kezelésére és a szegényügy szervezésére a Szentírásban leírtakat figyelembe véve, az Apostolok cselekedetei 6. része és a Pál apostol Timotheushoz írott levelének 3. részei alapján diakonusok-

\footnotetext{
${ }^{50}$ Mezey i.m. 13.

${ }^{51}$ Mezey B. i.m. 14.

${ }^{52}$ Laum i.m. 945.
} 
nak is nevezett „perselymestereket” kértek fel. A választott személyek (a „persely urai") évente nyilvános elszámolással tartoztak a közösségnek a bevételek és kiadások után.

A segélyezettekre vonatkozott a második alapelv, mely szerint, mivel segélyezni csak a valóban rászorultakat akarták, ennek megállapítására a persely urai környezettanulmányt készítettek, hogy megállapítsák kinek adható a segély. ${ }^{53}$

A harmadik alapelvet az egyházi közremúködés jelentette, ugyani sem Luther, sem Kálvin nem volt hajlandó feladni az egyházi szerepvállalást a szegénygondozásban (részben természetesen amiatt sem, mivel annak lényegi eleme volt - mint alapvetó egyházi szerep - a lelki gondozás is). Luther elképzeléseiben egy egészséges munkamegosztást feltételezett, ahol a szegénygondozással kapcsolatos adminisztratív teendők jó néhány részét az állami felsóbbség vállalja át. Kálvin elgondolásaiban az államtól független vallásos szegénygondozást tartott szükségesnek, nála viszont ennél a kérdésnél elmosódottabban jelennek meg a világi és egyházi igazgatás határai, amivel azonosultabb a felelősség.

Ezektől is némileg különböző, sajátos jellege alakult ki szegényekkel való foglalkozásnak Angliában, melynek egyik fő tétele volt, hogy a szegénygondozást teljesen állami ügyként kezelték. Ennek következménye volt a szigetországban, hogy egységesen, állami szankciókkal, az egész államra kiterjedô koldulási tilalmat valósítottak meg. Emellett itt - a reformáció más országaiban ismeretlen módon - a világi forrásokat kiegészítő szegényadót is szedtek.

Szintén angol sajátosságként találkozunk azzal a jellegzetes megoldással, hogy a gondoskodás centrumában nem a munkaképtelenekról való gondoskodás, hanem a munkaképesek munkára fogása állt. (Az itt felsorolt különbségek persze csak hangsúlyokat jelentettek, nem az elesettek és a betegek gondozásának hiányát!)

Az újkorhoz közeledve kialakuló modern állami keretekben Európa más országaiban is megjelent az állami gondoskodás több dimenziója, köztük az egységes joggyakorlat kialakítása mellett a szegénygondozás is. A harmincéves háborút követôen pedig általánosságban is elmondható, hogy az állam vette át a szegényügyet. ${ }^{54}$

\section{Befejezés}

A XVI. században a szegénység óriási problémát jelentett, a kor gondjaira a reformátorok is nagy figyelmet fordítottak. A Szentírás szociális tanítását ismerve fordultak a nincstelenek, elhagyottak és betegek gondozása felé. A reformáció a centralizált szegénygondozás mellett foglalt állást, és ehhez új kereteket teremtett, valamint joglapot talált.

Az újkori Európában a társadalom szociális gondoskodásának alapja a reformáció szellemiségéból, teológiájából ered, és a reformátorok munkájában csírájában

\footnotetext{
${ }^{53}$ Laum i. m. 946.

${ }^{54}$ Mezey B. i.m. 15.
} 
megtalálhatók a modern szociális gondolkodás alapelemei. Ehhez kapcsolódik az a protestáns teológiai felfogás, mely szerint a társadalmi jólét alapja az istentisztelet, hiszen az élet maga is liturgia (kell, hogy legyen reménység szerint) a liturgia után. A „közjó” (ahogyan azt Kálvin mondta), az istentiszteletról kiáramló emberek munkája révén teremthetố meg, mert az ember egész élete istentisztelet kell legyen.

Ugyanakkor Kálvin társadalomhoz való odafordulásában olyan új embert formált meg, aki nem utolsósorban abban is kitünik, hogy múködési területén elsônek sikerült az éhséget és tömegnyomort megszüntetnie. Kálvin különös figyelmet szentelt a szociális háló megteremtésének, melynek elsôdleges eszköze a szegénygondozás volt. A kórházak szolgáltatását kiszélesítette a szegények, hajléktalanok istápolására, elhelyezésére. A genfi reformátor szemében elválaszthatatlanul összetartozott a népesség testi egészsége a lelki-szellemi egészséggel. Emellett a harmonikus polgár kiformálását célzó népjóléti elképzeléseit a diakónia társadalmasításával kívánta elérni.

A témával kapcsolatos kutatómunkámat elvégezve - bár oktatóként magam is tanítok szociális gondoskodás történetet, ha ezt a területet nem is ilyen mélységben - magam is érdeklődéssel tapasztaltam, valóban mekkora újítást, hatékony átformálást jelentett a szegénygondozásban (szociális gondoskodásban) a vizsgált korszak teológiai szemlélete, illetve milyen meghatározó volt ebben a reformátorok (elsôsorban Kálvin) felfogása, tevékeny szerepe.

Vizsgálatom egyik fontos következtetése, hogy ezek a 16. századi reformációval megfogalmazott, az elesettekkel, rászorultakkal kapcsolatos új segítségnyújtási elvek legtöbbje ma is aktuális, a hatékony probléma-megoldási tevékenység részét képezheti. Ezek közül kiemelnék néhányat:

Ismerve a társadalomban napjainkban is nagy mértékben megjelenô exklúziós ${ }^{55}$ (élet) helyzeteket az ebben a korszakban kialakult munkával kapcsolatos felfogás ma is alapelvként jelenhet meg: a munka a társadalomba való visszatérés egyik legfontosabb lehetséges útja és mindenkire vonatkozhat.

Természetesen ehhez kapcsolódik a szintén máig érvényes elv, hogy a valóságos rászorulóknak joguk van a segítségre, de ez azt is jelenti, hogy a munkaképes nincstelenek esetén ne pusztán az anyagi juttatásoknál maradjunk, hanem a szegénysegélyezés más formáit is fel kell használni, vagyis a naturáliákkal való segélyezés keretében a munkáltatásról is gondoskodni kell.

Alapvetôen tehát a munka, a közösség szorgos/hasznos tagjává tevô (a nem koldulásból vagy a segélyezésból megélni akaró) életvezetés ma is egy Isten számára üdvös, de ugyanakkor a társadalom számára is építő, hasznos életmintát jelenthet.

Az elemzett korszak egyik nagyon fontos alapelve az is, hogy nem elegendô önmagában a munkalehetôség felkínálása, a teljes körü szegénygondozás részét kellett, hogy képezze a lelki gondozás és a nevelés is. Anélkül, ha a mentális oldalra nem figyelünk oda ma is személytelen, „féloldalas” a segítségnyújtásunk. Ugyanez igaz a pénzbeni és természetbeni segítségnyújtásra is, mint ahogy tanulmányában Fazakas

\footnotetext{
${ }^{55}$ Napjaink egyik gyakran használt társadalompolitikai fogalma, a társadalmi kizáródás, kirekesztődés helyzetére.
} 
Sándor is találóan fogalmazza meg: a diakónia ma sem jó, ha gépies „levesosztássá” laposodik, ha elfeledkezünk a lelki dimenzióról.

Mint láttuk Kálvin már társadalmi-strukturális szinten is (az állam szerepe, a helyi közösség kötelezettsége a különböző hátrányokkal küzdő polgárainak ellátására, a diakónia rendszere, egyház és „,világ” összekapcsolódása a problémák megoldása érdekében, stb.) szemléli és kívánja megoldani a szegényekról való gondoskodást. Ezt a struktúrát sem mondhatjuk ma sem tökéletesnek, azaz folyamatos jobbítása szintén a segítő szakma visszatérő feladata (és akárcsak Kálvin szemléletében, abban erősen jelen kell lennie a szolidaritásnak!).

Napjainkban sem lehet kérdés a valóban rászorultak (pl. munkaképtelenek, fogyatékkal élők, stb.) tisztességes méltó módon való ellátása, gondozása. Viszont ugyanígy máig fontos alapelv a rászorultak (akár rendszeres, időközönkénti) „,szemrevételezése" is, vagyis a rászorultság körültekintô, szakmai szempontú mérlegelése ( ehhez azóta alkalmazott eszköz például a környezettanulmány készítése ).

Élő az adománygyújtéssel és osztással kapcsolatos filozófia is: ma is jellemzó szempont a szabályozott, ellenőrzött és koncentrált forráskezelési technika alkalmazása (a mostani „közösségi perselyek”-be kerülő bevételeknél is), hiszen az „elfecsérelt eszközöket” egyesíteni kell, és „az esetleges vagy összefüggéstelen segélyezés helyett szabályozott gondoskodással szolgálja a valóban rászorultakat" ${ }^{56}$

Szintén egyáltalán nem túnik avíttnak a túl magas kamat (uzsoráskodás) szembeni fellépés, figyelembe véve ugyanakkor a mérsékelten kamatozó kölcsön segítség jellegét (megfelelő feltételekkel), akár a problémák prevenciójaként is. Hiszen ma is igaz, hogy az elszegényedést legjobb megelôzni, melynek érdekében hozták létre a 16. században szegénygondozás szociális szervezeteit, közösségi egyesületeit, gondoskodtak a házi szegényekrôl.

Kálvin teológiai rendszerének, gyakorlati módszereinek köszönhetôen a keresztyénség szociális elkötelezettsége a reformáció meghatározó jellemzôjévé vált. Ez ma is a keresztyénség egyik legfőbb jellemzője kell, hogy legyen (a legtöbb esetben az is!).

A gazdagok és a szegények közötti közösség már lehet, hogy napjainkban sokak számára végképp idealizmusnak hat, mindenesetre Kálvin érvelését átgondolva (ld. 10. old.) hozzávéve azt a plusz, szolidaritást eredményező „lelki oldalt”, amire ő is utal, talán nem is annyira elképzelhetetlen.

A nagy reformátor atya azon gondolata pedig, mely szerint a földi javak végső soron Istentól kölcsönkapott javak (amelyek tulajdonjoga személyekhez kötött ugyan), a felebarát és a közösség hasznát és az emberek közötti békét kell, hogy szolgálják, tulajdonképpen a ,közjő" elvét jeleníti meg, amely a modern civilizált társadalmak egyik hatékonysági, a közösséget jellemző elégedettség egyik „mérôfoka".

Végül Bucernek a diakónusokra vonatkozó gondolata, azt hiszem, mai napig nem szorul magyarázatra és annak lényege akár a szociális munkások, segítô foglalkozásúak ismertetőjegye is lehet: „A cél az, hogy olyanok legyenek ók, akikben

\footnotetext{
${ }^{56}$ Laum i.m. 945.
} 
mindenki megbizik, és akiket mindenki szeret, akik e szolgálatra és igazi pásztori gondoskodásra kelló talentumot és buzgóságot kaptak."

A 16. századi református szegénygondozás fố elvei, iránya, akárcsak az Úr Jézus Krisztus, ma is élő a szegényekrôl, elesettekrôl való gondoskodásban. Református Egyházunk napjainkban is széleskörü és meghatározó intézményrendszerrel végzi a szociális segítségnyújtást, ezzel is teljesítve Isteni küldetését. Ezért hálát adunk a Mindenhatónak, ugyanakkor éppen emiatt sosem feledhetjük azt sem, hogy mindnyájunknak áldott lehetôsége és átháríthatatlan felelôssége, hogy Isten elfogadott és megtapasztalt szeretetének bizonyossága legyen a szenvedô, szúkölködő, megpróbált életû felebarátunk iránt bizonyított megértô szeretetünk és áldozatokat vállaló segítségünk, hiszen

„A magunk részéról nem úgy tekintjük tisztségünket, mint amely oly módon lenne behatárolva, hogy amikor a prédikáció véget ér, feladatunk elvégzett lenne. ${ }^{57}$

\section{Egyéb felhasznált szakirodalom}

1. Szent Biblia Magyar Bibliatársulat, Bp. 2005.

2. Atkinson, James: A reformáció. In: A kereszténység története. Budapest, Lilliput Könyvkiadó, 1996.

3. Barker, Robert L. - Almási Judit: Mérföldkövek a szociális munkáltatásban. Budapest, Budapesti Szociális Forrás Központ, 1996.

4. Dr. Pálos Károly: Szegénység, szegénygondozás. Szombathely, Martineum Nyomda. 1934.

5. Johnson, Paul: A kereszténység története. Budapest, Európa, 2001.

6. www.reformiert-info.de

7. www. reformatus.hu - Luther élete.

8. Southern, Richard Williams: A nyugati társadalom és az egyház a középkorban Budapest, Gondolat, 1987.

9. Joachim Staedtke Kálvin János: Megismerés és formálódás. Személyiség és történelem - 48. kötet - Életrajzi sorozatok Musterschmidt-Verlag - Göttingen . Zürich . Frankfurt Kia.: Prof. dr. Günter Franz és prof. dr. Gustav Adolf Rein.

Ferenczi Gábor: főiskolai adjunktus

Debreceni Egyetem, Egészségügyi Kar, Nyíregyháza, 4400, Sóstói út 2-4.

\footnotetext{
${ }^{57} 58$ Johannis Calvini. Articles Concernant l'organisation de l'église et du culte a Géneve, proposés au conseil par les ministres, Le 16. Janvier 1537, in: Opera Selecta ( OS ), Vol. I, Ed. Petrus Barth, Monachii Chr. Kaiser 1926, ( 369-377 ), 376. - Vö. Joachim Staedtke: Johannes Calvin Erkenntnis und Gestaltung. Göttingen-Zürich- Frankfurt 1969, 92. Idézi Dr. Fazakas S. 104.
} 